\title{
Effects of Freeze Drying on Antioxidants and Immunoglobulins Level of Zebu Bovine Colostrum
}

\author{
Dushyant Kumar Sharma*, Debabrata Mondal, R. Raguvaran, \\ Arvind Kumar Das and Narayani Yadav
}

\author{
Division of Medicine, ICAR-Indian Veterinary Research Institute, Izatnagar, \\ Bareilly-243122, U.P. India \\ *Corresponding author
}

\section{A B S T R A C T}

\section{Keywords \\ Freeze drying, Bovine colostrum, Antioxidant, Immunoglobulins, Zebu \\ Article Info \\ Accepted: \\ 26 July 2020 \\ Available Online: \\ 10 August 2020}

\begin{abstract}
The aim of present study was to investigate the effect of freeze drying on total antioxidant and immunoglobulin levels of bovine colostrum in desi breed (Zebu cattle). A total of 12 colostrum samples were collected from the desi breed (Zebu cattle) reared at LPM section of IVRI, Izatnagar. Collected colostrum was converted aseptically into dry powder form by freeze drying at (-) $40^{\circ} \mathrm{C}$ with low pressure. Antioxidant content was analysed using free radical scavenging activity (DPPH assay) and total antioxidant capacity (FRAP assay).Qualitatively and quantitative immunoglobulin level was assessed by zinc sulphate turbidity and IgG estimation respectively. Average reduction in DPPH scavenging activity was found to be $35.04 \%$ on freeze drying whereas average reduction of FRAP value was found to be $14.96 \%$ on freeze drying. Immunoglobulin content of bovine colostrum was decreased by $23.86 \%$ of ZST unit after freeze drying whereas with respect to IgG level, the average percentage reduction was $26.05 \%$ after freeze drying of bovine colostrum. Present study concludes that freeze drying reduces antioxidants and immunoglobulin level of bovine colostrum.
\end{abstract}

\section{Introduction}

Bovine colostrum (BC) is the first lacteal secretion after parturition up to $72 \mathrm{hr}$ which is a rich source of immunologically active components and capable of transferring passive immunity to the offspring and also termed as "Immune milk" (Nikolic et al., 2017). It has become increasingly popular as a nutritional supplement in humans also for immune support. BC is a rich source of antioxidants both enzymatic and non- enzymatic. Enzymatic antioxidants in colostrum include lactoperoxidase (Shin et al., 2000), catalase (Ito and Akuzawa, 1983), superoxide dismutase (Hill, 1975; Asada, 1976; Korycka-dahl et al., 1979) and glutathione peroxidase (Hojo, 1982). Nonenzymatic antioxidants in colostrum include vitamin E (Goff et al., 2002), Vitamin A (Schweigert and Eisek, 1990; Kume and Toharmat, 2001), vitamin C (LindmarkMansson and Akesson, 2000), lactoferrin (Bennett et al., 1986) and selenium (Debskiet 
al., 1987). Persisting copper, zinc and cysteine in BC acts as cofactors of which copper and Zinc are necessary for proper activity of antioxidative enzymes and also itself possess its (Ahmed et al., 2004). Cysteine is a precursor of glutathione (Goldmas et al., 1986). Caseins and whey proteins from colostrum exert their antioxidant activities which can be measured by reducing power, ferrous ion chelating abilities as well as inhibitory effects on lipid peroxidation (Chiang and Chang, 2005).

BC contains several hundred-fold immunoglobulin (Ig) of physiologically bioactive constituents such as growth promoting factors (IGF I and II) as well as a series of antimicrobial and antioxidant peptide including lactoferrin, lactoperoxidase and lysozymes than ordinary bovine milk (Sanchez et al., 1992; Levay and Viljoen, 1995; Lonnerdal and Lyer, 1995; Korhonen et al., 1995). The most abundant immunoglobulin class in bovine milk and colostrum is $\operatorname{IgG} 1$, while $\operatorname{IgA}$ and $\operatorname{IgM}$ are present at minimum concentrations. Other important components are various oligosaccharides, acute phase proteins, growth factors, antimicrobial peptides and others (Stelwagen et al., 2009).

Freeze-drying is the most preferred dehydration method for heat-sensitive biological material, as the low processing temperature and rapid local transition of frozen material from hydrated to dehydrated state minimize nutrient losses. Chelack et al., (1993) reported a $10 \%$ loss in biological activity of immunoglobulins upon freezedrying of colostrum, whereas Elfstrand et al., (2002) reported $34 \%$ and $25 \%$ losses in total immunoglobulins during freeze-drying of colostrum whey and colostrum concentrate prepared from the whey through the application of membrane filtration. Freezedrying had a significant detrimental effect (i.e., $30 \%$ loss) on native TGF-b2 and IGF-1 of a colostrum concentrate, and minor effect on freeze-dried colostrum whey (Elfstrand $e t$ al., 2002). Lyophilised colostrum is reported to be stable, easy to handle and suitable for passive immunization (Husu et al., 1993). The present study envisaged to investigate the effect of freeze drying on total antioxidant and immunoglobulin content of bovine colostrum in desi breed (Zebu cattle).

\section{Materials and Methods}

\section{Collection and preparation of freeze dried bovine colostrum (FDBC)}

Excess colostrum at the time of first milking was collected from Indian zebu cattle reared at LPM section (Cattle \& Buffalo farm), ICAR - IVRI, Izatnagar under strict hygiene. A total of 12 samples were collected from the desi breed (Zebu cattle). The collected colostrum was transported to laboratory in cold condition and kept at $-20^{\circ} \mathrm{C}$ till processing. The collected colostrum was thawed and subjected to freeze drying at $-40^{\circ}$ $\mathrm{C}$ with low pressure to make it as dry powder and kept under cold condition for further use (Klobasa et al, 1998).

\section{Antioxidant potential of FDBC}

Antioxidant activity of FDBC was assessed by following methods. All the samples were analysed in triplicate and average values were noted.

\section{Free radical scavenging activity (DPPH} method)

The free radical scavenging activity of FDBC was measured by DPPH (1, 1 diphenyl 2, picrylhydrazyl) assay with slight modification (Brand-Williams et al., 1995). It measures the free radical scavenging activity in terms of hydrogen donating ability or radical 
scavenging property of any biological fluids using the stable free radical DPPH solution. Colostrum sample $(100 \mu \mathrm{l})$ was mixed with 2 $\mathrm{ml}$ of DPPH solution $(0.2 \mathrm{mM})$ prepared in methanol. The mixture was allowed to incubate at room temperature for $30 \mathrm{~min}$. After completion of incubation period, $1 \mathrm{ml}$ of chloroform was added and centrifuged at $3000 \mathrm{x} \mathrm{g}$ for $5 \mathrm{~min}$. The absorbance of clear solution was measured at $517 \mathrm{~nm}$. A $100 \mathrm{mM}$ of DPPH solution prepared in methanol was used as a control. The percentage inhibition of DPPH free radical (scavenged \%) was calculated based on reading of control solution by employing the following equation:

Scavenging activity $(\%)=[($ absorbance of the control - absorbance of the sample)/ absorbance of the control] $\times 100$

\section{FRAP assay to determine total antioxidant activity}

To determine the total antioxidant capacity of colostrum, a modified FRAP assay was used with little modification (Benzie and Strain, 1996). FRAP reagent was freshly prepared by mixing $300 \mathrm{mmol} / \mathrm{L}$ acetate buffer $(3.1 \mathrm{~g}$ of $\mathrm{CH}_{3} \mathrm{COONa}$ and $16 \mathrm{ml}$ of $\left.\mathrm{CH} 3 \mathrm{OOH}\right), \mathrm{pH}$ 3.6, $10 \mathrm{mmol} / \mathrm{L}$ TPTZ (2, 4, 6-tripyridyl-striazine) in $40 \mathrm{mmol} / \mathrm{L} \mathrm{HCl}$ and $20 \mathrm{mmol} / \mathrm{L}$ $\mathrm{FeCl}_{3}$ in 10:1:1 ratio. Colostrum sample (50 $\mu \mathrm{l})$ was mixed with $1.5 \mathrm{ml}$ of FRAP reagent and kept at dark for 10 minutes. The resulting intense blue colouration (Ferrous tripyridyltriazine complex) was subsequently measured at $593 \mathrm{~nm}$. Aqueous solutions of $\mathrm{FeSO}_{4} \cdot 7 \mathrm{H}_{2} \mathrm{O}(100-1000 \mu \mathrm{M})$ was used as standard curve. The data was expressed as FRAP values $(\mu \mathrm{M} / \mathrm{mL}$ Fe (II)).

\section{Immunoglobulin assessment}

\section{Zinc sulphate turbidity test (ZST)}

Zinc sulphate turbidity test was done to determine the immunoglobulins present in
FDBC. Zinc sulphate turbidity reaction (ZST) was measured using McEvan's method with little modifications (McEvan et al., 1970; Hogan et al., 2016). Colostrum serum was collected by using $10 \%$ acetic which precipitated the casein protein at $37^{\circ} \mathrm{C}$. The fat was separated by adding diethyl ether and ethanol. $50 \mu \mathrm{l}$ of the tested colostrum serum was mixed with $3.4 \mathrm{~mL}$ of zinc sulphate $(350$ $\mathrm{mg} / \mathrm{l})$ solution which was immediately prepared in boiling water bath in a screw capped tube. The mixture was shaken and left to stand at room temperature for 60 minutes. Light absorption due to turbidity was measured photometrically at $680 \mathrm{~nm}$. The immunoglobulins contents of the tested sample were derived from a calibration curve plotted on a basis of turbidity values corresponding to different dilutions of the standard barium sulphate solution. Six ml of $11.5 \mathrm{~g} / \mathrm{l} \mathrm{BaCl} 2$ solution was made up to 200 $\mathrm{ml}$ in a volumetric flask with $0.2 \mathrm{~N} \mathrm{H}_{2} \mathrm{SO}_{4}$. The absorbance of this barium sulphate standard was measured spectrophometrically and the resultant absorbance value was assigned a value of $12.5 \mathrm{ZST}$ units. ZST unit of the tested samples were calculated from standard curve.

\section{IgG estimation}

IgG was estimated in bovine colostrum as well as freeze dried bovine colostrum by Quantia IgG kit with the modification of human IgG was replaced with bovine specific IgG. Colostrum serum was prepared following the method casein precipitation with $10 \%$ acetic acid method. A calibration curve was plotted against concentration and absorbance to find the linear equation.

\section{Results and Discussion}

For uniqueness of result, all the tests performed both with BC and FDBC. Freeze drying of bovine colostrum was done to make 
it dry powder at (-) $40^{\circ} \mathrm{C}$ and low pressure using standard protocol. Freeze drying efficiency was calculated for every representative sample. Average percentage recovery of freeze dried bovine colostrum was $21.67 \%$. Collected BC was pale yellow in colour which after freeze drying converted into light pale crystalline powder.

\section{Antioxidant potential of FDBC}

Antioxidant activity of FDBC was assessed by free radical scavenging activity (DPPH methods) and Total antioxidant activity (FRAP assay) methods.

\section{Free radical scavenging activity (DPPH methods)}

Free radical scavenging activity of biological samples was determined by DPPH assay which is based on the electron donation or hydrogen atom acceptance. In the present study, 12 first day bovine colostrum (BC) and their corresponding FDBC samples were analysed by DPPH methods. All the samples were analysed in triplicates. Scavenging activity of bovine colostrum and corresponding FDBC has been depicted in the
Table 2. The average scavenging activity of $\mathrm{BC}$ was $50.46 \%$ whereas the average scavenging activity of FDBC was found to be $32.75 \%$ which revealed a reduction in the DPPH scavenging activity after freeze drying. Average reduction in DPPH scavenging of $\mathrm{BC}$ was found to be $35.04 \%$ after freeze drying.

\section{Total antioxidant activity (FRAP assay)}

Total antioxidant activity of colostrum samples and FDBC was determined by FRAP assay. In the present study, 12 first day bovine colostrum and their corresponding FDBC samples were evaluated by FRAP methods. All the samples were analysed in triplicates. A standard regression equation $\left(\mathrm{R}^{2}=0.9917\right)$ was plotted using freshly prepared aqueous solution of ferrous sulphate solution (100$1000 \mu \mathrm{M})$ and absorbance. Concentration of FRAP value of $\mathrm{BC}$ and FDBC were derived using the linear equation and expressed as $\mu \mathrm{M} / \mathrm{mL} \mathrm{Fe}$ (II). The average FRAP value for $\mathrm{BC}$ and FDBC were $876.83 \mu \mathrm{M} / \mathrm{mL}$ Fe (II) and $745.87 \mu \mathrm{M} / \mathrm{mL}$ Fe (II) respectively. Average reduction of FRAP value on freeze drying was found to be $14.96 \%$. The data has been presented in Figure 2 and table 3.

Table.1 Yield percentage of freeze dried bovine colostrum

\begin{tabular}{|c|c|c|c|}
\hline Sl. No. & $\begin{array}{c}\text { Weight of Colostrum } \\
\text { (gm) }\end{array}$ & $\begin{array}{c}\text { Weight of FDBC } \\
(\mathbf{g m})\end{array}$ & \% Yield \\
\hline BC-1 & 16.25 & 2.93 & $\mathbf{1 8 . 0 3}$ \\
\hline BC-2 & 15.40 & 2.78 & $\mathbf{1 8 . 0 5}$ \\
\hline BC-3 & 15.48 & 2.88 & $\mathbf{1 8 . 6 0}$ \\
\hline BC-4 & 15.20 & 2.72 & $\mathbf{1 7 . 8 9}$ \\
\hline BC-5 & 16.15 & 3.06 & $\mathbf{1 8 . 9 4}$ \\
\hline BC-6 & 15.24 & 2.98 & $\mathbf{1 9 . 5 5}$ \\
\hline BC-7 & 25.29 & 6.15 & $\mathbf{2 4 . 3 1}$ \\
\hline BC-8 & 24.28 & 5.92 & $\mathbf{2 4 . 3 8}$ \\
\hline BC-9 & 24.35 & 6.03 & $\mathbf{2 4 . 7 6}$ \\
\hline BC-10 & 24.20 & 6.32 & $\mathbf{2 6 . 1 1}$ \\
\hline BC-11 & 25.14 & 6.04 & $\mathbf{2 4 . 0 3}$ \\
\hline BC-12 & 24.80 & 6.29 & $\mathbf{2 5 . 3 6}$ \\
\hline \multicolumn{2}{|c|}{ Average yield of FDBC from all samples } & $\mathbf{2 1 . 6 7 \%}$ \\
\hline
\end{tabular}


Table.2 Scavenging activity of BC and FDBC with \% reduction of Scavenging activity upon freeze drying

\begin{tabular}{|c|c|c|c|}
\hline Sl. no & $\begin{array}{c}\text { \% Scavenging } \\
\text { activity of BC }\end{array}$ & $\begin{array}{c}\text { \% Scavenging } \\
\text { activity of FDBC }\end{array}$ & $\begin{array}{c}\text { \% Reduction on } \\
\text { freeze drying }\end{array}$ \\
\hline BC 1 & 50.53 & 33.31 & 34.06 \\
\hline BC 2 & 45.95 & 29.32 & 36.19 \\
\hline BC 3 & 53.92 & 33.75 & 37.42 \\
\hline BC 4 & 52.60 & 34.81 & 33.82 \\
\hline BC 5 & 51.93 & 31.01 & 40.30 \\
\hline BC 6 & 53.30 & 30.18 & 43.37 \\
\hline BC 7 & 45.88 & 31.19 & 32.01 \\
\hline BC 8 & 51.90 & 34.99 & 32.57 \\
\hline BC 9 & 48.49 & 31.58 & 34.88 \\
\hline BC 10 & 53.01 & 36.80 & 30.57 \\
\hline BC 11 & 47.79 & 30.62 & 35.93 \\
\hline BC 12 & 50.20 & 35.43 & 29.41 \\
\hline Average & $\mathbf{5 0 . 4 6}$ & $\mathbf{3 2 . 7 5}$ & $\mathbf{3 5 . 0 4}$ \\
\hline
\end{tabular}

Table.3 FRAP assay of BC and FDBC with \% reduction of FRAP value upon Freeze drying

\begin{tabular}{|c|c|c|c|}
\hline Sl. no & $\begin{array}{c}\text { FRAP value of BC } \\
{[\boldsymbol{\mu M} \mathbf{m} \mathbf{m} \mathbf{~ F e}(\mathbf{I I})]}\end{array}$ & $\begin{array}{c}\text { FRAP Value of FDBC } \\
{[\boldsymbol{\mu M} \mathbf{m} \mathbf{m} \mathbf{F e}(\mathbf{I I})]}\end{array}$ & $\begin{array}{c}\text { \% Reduction in FRAP value } \\
\text { upon freeze drying }\end{array}$ \\
\hline BC 1 & 819.70 & 690.37 & 15.74 \\
\hline BC 2 & 932.03 & 826.20 & 11.35 \\
\hline BC 3 & 930.87 & 769.70 & 17.31 \\
\hline BC 4 & 844.20 & 733.20 & 13.15 \\
\hline BC 5 & 970.70 & 865.37 & 10.85 \\
\hline BC 6 & 803.03 & 671.37 & 16.40 \\
\hline BC 7 & 914.70 & 741.87 & 18.89 \\
\hline BC 8 & 941.37 & 800.20 & 15.00 \\
\hline BC 9 & 892.03 & 773.37 & 13.31 \\
\hline BC 10 & 847.37 & 724.53 & 14.49 \\
\hline BC 11 & 745.53 & 638.20 & 14.39 \\
\hline BC 12 & 880.37 & 716.03 & 18.65 \\
\hline Average & $\mathbf{8 7 6 . 8 3}$ & $\mathbf{7 4 5 . 8 7}$ & $\mathbf{1 4 . 9 6}$ \\
\hline
\end{tabular}


Table.4 Zinc sulphate turbidity test of BC, FDBC and \% reduction upon freeze drying

\begin{tabular}{|c|c|c|c|}
\hline Sl.no & $\begin{array}{c}\text { BC } \\
\text { (ZST unit) }\end{array}$ & $\begin{array}{c}\text { FDBC } \\
\text { (ZST unit) }\end{array}$ & $\begin{array}{c}\text { \% Reduction on } \\
\text { freeze drying }\end{array}$ \\
\hline BC 1 & 65.92 & 50.55 & 23.32 \\
\hline BC 2 & 65.69 & 48.65 & 25.93 \\
\hline BC 3 & 59.57 & 49.31 & 17.23 \\
\hline BC 4 & 67.47 & 52.63 & 21.99 \\
\hline BC 5 & 61.12 & 48.06 & 21.36 \\
\hline BC 6 & 73.22 & 53.34 & 27.15 \\
\hline BC 7 & 61.53 & 46.69 & 24.11 \\
\hline BC 8 & 75.24 & 53.82 & 28.47 \\
\hline BC 9 & 70.26 & 52.04 & 25.93 \\
\hline BC 10 & 72.21 & 54.53 & 24.49 \\
\hline BC 11 & 75.30 & 58.50 & 22.30 \\
\hline BC 12 & 71.03 & 55.12 & 22.39 \\
\hline Average & $\mathbf{6 8 . 2 1}$ & $\mathbf{5 1 . 9 4}$ & $\mathbf{2 3 . 8 6}$ \\
\hline
\end{tabular}

Table.5 Concentration of $\mathrm{IgG}$ in $\mathrm{BC}$ and $\mathrm{FDBC}$ with \% reduction in $\mathrm{IgG}$ upon Freeze drying

\begin{tabular}{|c|c|c|c|}
\hline Sl. no & IgG Conc. of BC (mg/d) & $\begin{array}{c}\text { IgG Conc. of FDBC } \\
(\mathbf{m g} / \mathbf{d l})\end{array}$ & \% reduction in IgG \\
\hline BC 1 & 781.0 & 591.0 & 24.33 \\
\hline BC 2 & 773.5 & 573.5 & 25.86 \\
\hline BC 3 & 713.5 & 586.0 & 17.87 \\
\hline BC 4 & 728.5 & 598.5 & 17.84 \\
\hline BC 5 & 803.5 & 603.5 & 24.89 \\
\hline BC 6 & 778.5 & 583.5 & 25.05 \\
\hline BC 7 & 771.0 & 556.0 & 27.89 \\
\hline BC 8 & 803.5 & 553.5 & 31.11 \\
\hline BC 9 & 828.5 & 573.5 & 30.78 \\
\hline BC 10 & 771.0 & 571.0 & 25.94 \\
\hline BC 11 & 803.5 & 566.0 & 29.56 \\
\hline BC 12 & 838.5 & 591.0 & 29.52 \\
\hline Average & $\mathbf{7 8 2 . 8}$ & $\mathbf{5 7 8 . 9}$ & $\mathbf{2 6 . 0 5}$ \\
\hline
\end{tabular}

Fig.1 Fresh bovine colostrum (BC) after collection, (B) Freeze dried bovine colostrum (FDBC)
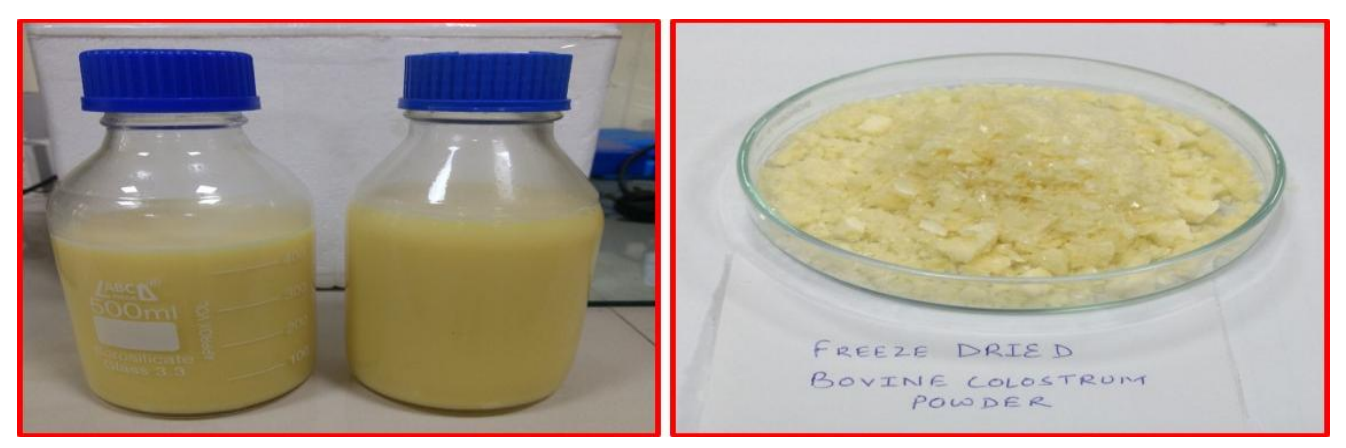
Fig.2 Ferrous sulphate calibration curve

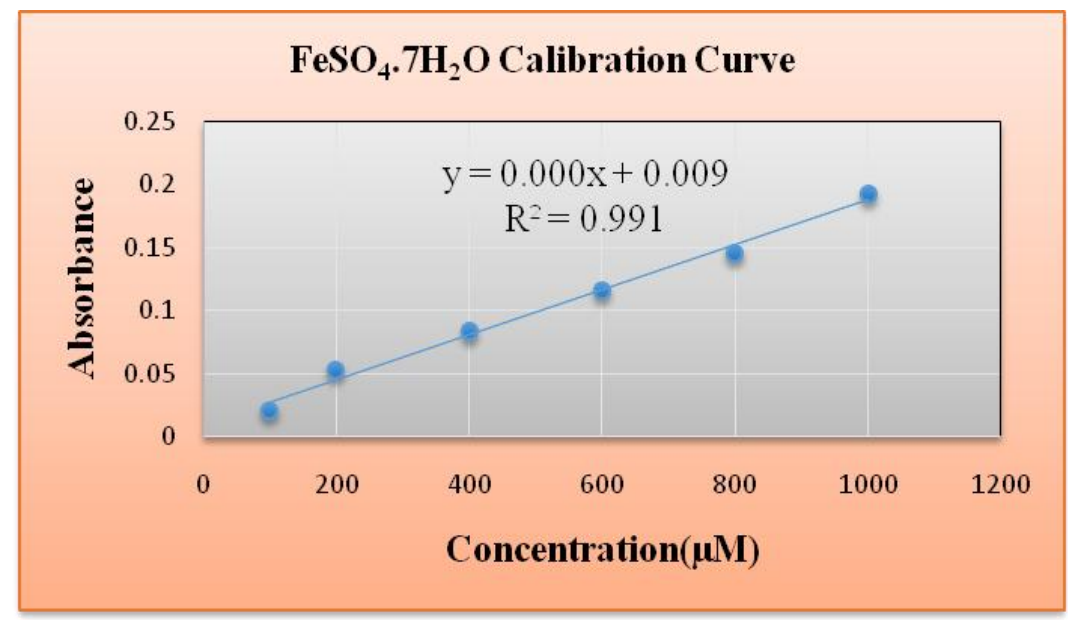

Fig.3 Barium sulphate calibration curve

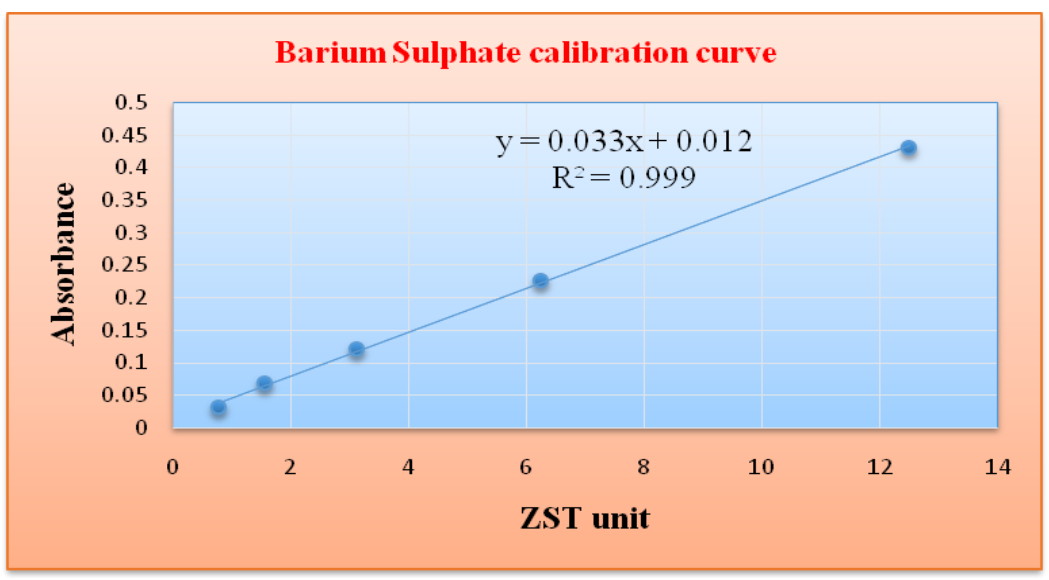

Fig.4 IgG calibration curve

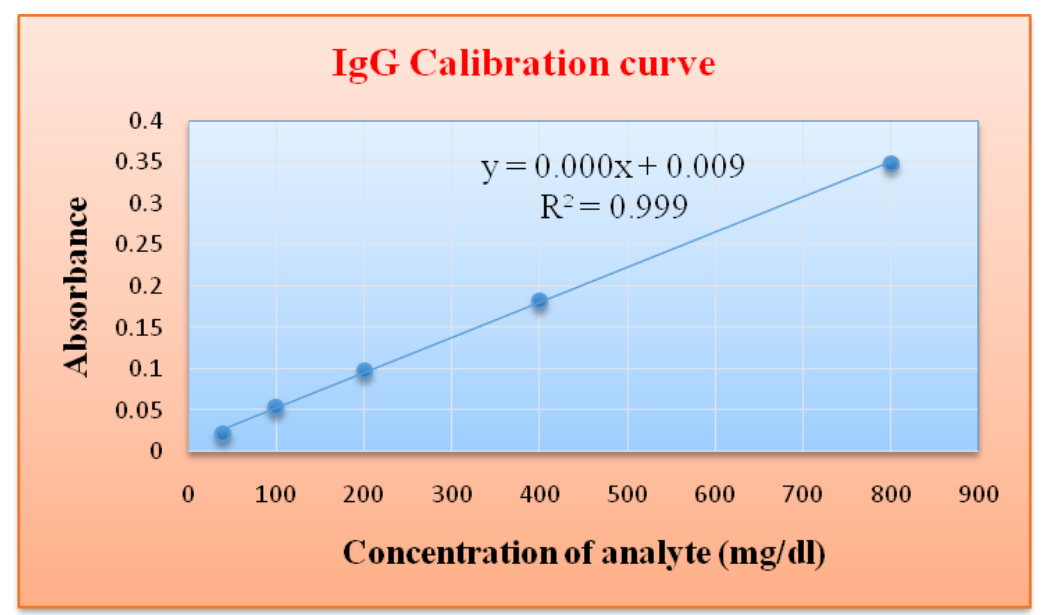




\section{Immunomodulatory potential of FDBC}

Immunomodulatory potential of FDBC was assessed by zinc sulphate turbidity test (ZST) and $\mathrm{IgG}$ concentration estimation in colostrum serum.

\section{Zinc sulphate turbidity test (ZST)}

Zinc sulphate turbidity test was done to estimate the immunoglobulins content of $\mathrm{BC}$ and FDBC serum which is qualitative test. A stand regression equation was plotted using serial dilution of barium sulphate $\left(\mathrm{R}^{2}=0.9991\right)$. Immunoglobulin content was estimated using absorbance by linear equation plotted and represented in ZST unit/ dl. The average content of immunoglobulin in $\mathrm{BC}$ and FDBC was found to be 68.21 ZST unit/dl and 58.94 ZST unit/dl. Data analysis of BC and FDBC revealed reduction of $23.86 \%$ ZST unit after freeze drying. The data has been presented in Figure 3 and table 4.

\section{Immunoglobulin G estimation}

IgG was estimated in bovine colostrum as well as freeze dried bovine colostrum by Quantia IgG kit with the modification of human IgG was replaced with bovine specific IgG. Colostrum serum was prepared following the method casein precipitation with $10 \%$ acetic acid method. The average concentration of $\operatorname{IgG}$ in $\mathrm{BC}$ and $\mathrm{FDBC}$ was $782.8 \mathrm{mg} / \mathrm{dl}$ and $578.9 \mathrm{mg} / \mathrm{dl}$ respectively. The average percentage reduction of $\mathrm{IgG}$ was calculated to be $26.05 \%$. The data has been presented in Figure 4 and table 5.

Bovine colostrum of zebu cattle was processed by lyophilisation and dried powdered colostrum was recovered. The recovery percentage was $21.67 \%$ which is approximately equivalent to the total solid $(22.0 \%)$ depicting the removal of water by freeze drying process. During freeze drying process, water is sublimated at low temperature $\left(-40{ }^{\circ} \mathrm{C}\right)$ with low pressure to preserve the thermolabile component of biological samples (Nireesha et al., 2013) to prolong the self-life and storage quality. Basically, colostrum as such cannot be stored for longer period due to possible microbial attack. So, freeze drying process removes the watery component and decrease water activity of the biological sample thereby increases self-life of colostrum with minimum loss of the active components. Pasteurization and other heat treatment methods have been reported to produce detrimental effect on protein by denaturing the original structure of protein components (Moreti et al., 2012).

Bovine colostrum is a combined source of enzymatic and non-enzymatic antioxidants (Pandey et al., 2011). These antioxidants have potential to protect the body from excessive production of free radicals or ROS, a process commonly linked to oxidative tissue injury and may be useful as a therapeutics of certain diseases like cancers, diabetes mellitus etc (Jackson et al., 2002).

The free radical scavenging activity of biological samples was determined by DPPH assay which is based on the electron donation or hydrogen atom acceptance. In present study, the average scavenging activity of BC was $50.46 \%$ whereas the average scavenging activity of FDBC was found to be $32.75 \%$. Mann et al., (2016) reported free radical scavenging activity of $55.42 \pm 0.50 \%$ in Sahiwal cattle (Indian Zebu cattle). Present findings reported that decreased DDPH scavenging activity after freeze drying might be due to loss of some antioxidant component during the process. Similar findings were reported on losses of active components of colostrum and colostrum whey during freeze drying process (Chelack et al., 1993: Elfstrand et al., 2002). 
The FRAP assay evaluates the capacity to reduce ferric ions of any biological sample. The present study revealed total antioxidant activity (FRAP Value) of BC and FDBC were $876.83 \mu \mathrm{M} / \mathrm{ml} \mathrm{Fe}$ (II) and $745.87 \mu \mathrm{M} / \mathrm{ml} \mathrm{Fe}$ (II) respectively. Similar finding was reported by Mann et al., (2016) who stated that FRAP values for Sahiwal cow colostrum was found to be $627.38 \mu \mathrm{M} / \mathrm{ml} \mathrm{Fe}$ (II) and also reported that FRAP value decreases with the lactation progress. The present studies revealed average reduction of FRAP value after freeze drying and was $(14.96 \%)$ which could be explained as loss of some component during the process. Similar findings were also reported on losses of active components of colostrum and colostrum whey during freeze drying process (Chelack et al., 1993: Elfstrand et al., 2002).

Bovine colostrum is a condensed source of immunoglobulins such as $\operatorname{IgG}, \operatorname{IgM}, \operatorname{IgA}$, $\mathrm{IgD}$, and $\operatorname{IgE}$. IgG and $\operatorname{IgM}$ play important role to protection from invading bacteria, virus and fungi and parasites whereas $\operatorname{Ig} \mathrm{A}$ protects the intestinal surface and facilitates the removal of microorganisms thus inhibiting the first step of infection. When given orally, immunoglobulins in colostrum protect rabbits from E.coli infection due to improvement of cell mediated or humoral immunity (Nagaraja, 2010; Pandey et al., 2011).

Total immunoglobulin was estimated qualitatively using zinc sulphate turbidity test in BC serum and FDBC serum in ZST unit/ dl. The average content of immunoglobulin in $\mathrm{BC}$ and FDBC was found to be $68.21 \mathrm{ZST}$ unit/dl and 58.94 ZST unit/dl respectively. The data analysis of BC and FDBC revealed a reduction of $23.86 \% \mathrm{ZST}$ unit upon freeze drying. Zinc sulphate test is a qualitative method used to determine the immune status of neonatal animals. This estimation gives a total globulin status rather than specific globulin described by McEvan et al., (1970).
According to the Hogan et al., (2016), 1 ZST unit is equivalent to the $10 \mathrm{mg} / \mathrm{ml}$ of immunoglobulins. Present study revealed the $23.86 \%$ of reduction of immunoglobulins after freeze drying of $\mathrm{BC}$ which is in accordance with the Elfstrand et al., (2002) who reported $25 \%$ losses in total immunoglobulins during freeze drying of colostrum whey.

IgG was estimated in bovine colostrum as well as freeze dried bovine colostrum by Quantia IgG kit with the replacement of Human IgG with Bovine specific IgG. The average concentration of IgG was $782.8 \mathrm{mg} / \mathrm{dl}$ and $578.9 \mathrm{mg} / \mathrm{dl}$ in $\mathrm{BC}$ and FDBC respectively. The average percentage reduction of IgG was $26.05 \%$. Chelack et al., (1993) reported a $10 \%$ loss in biological activity of Immunoglobulin $G$ upon freezedrying of colostrum, whereas Elfstrand et al., (2002) reported $34 \%$ and $25 \%$ losses in total Ig during freeze-drying of colostrum whey and colostrum concentrate prepared from the whey through application of membrane filtration.

In conclusion the Study revealed reduction in total antioxidant capacity, DPPH \% scavenging activity as well as low reduction in immunoglobulin level after freeze drying of zebu cattle colostrum. However decrease in water activity of fresh bovine colostrum increases the self-life for antioxidant and immunomodulatory property of freeze dried bovine colostrum. Hence freeze dried bovine colostrum supervened fresh bovine colostrum and may be a potent source of antioxidant and immunoglobulin supplementation in ailing as well as ill thrift conditions of animals.

\section{Acknowledgement}

Authors are thankful to Director, IVRI, Izatnagar for providing financial support to conduct this research. 


\section{References}

Ahmed,L., Nazrul Islam, S.K., Khan, N.I., Huque, S. and Ahsan, M.(2004). Antioxidant micronutrient Profile (Vitamin E, C, A, copper, zinc, iron) of colostrum. Association with maternal characteristics. J. Trop. Pediatr. 50:357358.

Asada, K. (1976). Occurrence of superoxide dismutase in bovine milk. Agric. Biol. Chem. 40: 1659-1660.

Bennett, R.M., Menlt, M.M. and Gabor,G. (1986). Lactofferin binds to neutrophilic membrane DNA. Brit. J. Haematol. 63: 105-117.

Benzie I. F. and Strain, J. J. (1996). The ferric reducing ability of plasma (FRAP) as a measure of antioxidant power: the FRAP assay. Anal. Biochem. 239(1): 70-76.

Brand-Williams W, Cuvelier M.E., and Berset. C. (1995) Use of a free radical method to evaluate antioxidant activity. Lebensm. Wiss. Technol. 28(1): 25-30.

Chelack, B.J., Morley, P.S. and Haines, D.M. (1993). Evaluation of methods for dehydration of bovine colostrum for total replacement of normal colostrum in calves. Can.Vet. J. 34: 407-412.

Chiang, S.H. and Chang, C.Y. (2005). Antioxidant properties of caseins and whey proteins from colostrums. J. Food Drug Anal. 13: 57-63

Debski, B., Picciano, M.F. and Milner, J.A. (1987). Selenium content and distribution of human, cow and goat milk. J. Nutr. 117:1091-1097.

Elfstrand, L., Lindmark-Mansson, H., Paulsson, M., Nyberg, L. and Akesson, B. (2002). Immunoglobulins, growth factors and growth hormone in bovine colostrum and the effects of processing. Int. Dairy J. 12:879-887.

Goff, J.P., Kimura, K. and Horst, R.L. (2002). Effect of mastectomy on milk fever, energy and vitamins $\mathrm{A}, \mathrm{E}$ and $\mathrm{a}$-carotene status at parturition. J. Dairy Sci.,
85:1427-1436

Goldmas, A.S., Thorpe, L.W., Goldblum, R.M. and Hanson, K.A. (1986). Antiinflammatory properties of human milk. ActaPaediatr Scand. 75: 689-695.

Hill, R.D. (1975). Superoxide dismutase activity in bovine milk. Aust. J. Dairy. Tech., 30:26-28.

Hogan, I., Doherty, M., Fagan, J., Kennedy, E., Conneely, M., Crowe, B., and Lorenz, I. (2016). Optimisation of the zinc sulphate turbidity test for the determination of immune status. Vet. Record, vetrec-2015.

Hojo, Y. (1982). Selenium concentration and glutathione peroxidase activity in cow's milk. Biol. Trace Elem. Res. 4:233-239.

Husu, J., Syvaoja, E.L., Ahola-Luttila, H., Kalsta, H., Sivela, S. and Kosunen, T.U.(1993). Production of hyperimmune bovine colostrum against Campylobacter jejuni. J. Appl. Bacteriol. 74(5):564-569.

Ito, O. and Akuzawa, R. (1983). Isoenzymes of bovine milk catalase. J. Dairy Sci., 66: 2468-2473.

Jackson M.J., Papa, S., Bolanos, J., Bruckdorfer, R., Carlsen, H., et. al. (2002) Antioxidants, reactive oxygen and nitrogen species, gene induction and mitochondrial function. Mol Aspects Med. 23(1): 209-285.

Klobasa, F., Goel, M. C. andWerhahn, E. (1998). Comparison of freezing and lyophilizing for preservation of colostrum as a source of immunoglobulins for calves. J. Ani. Sci. 76(4): 923-926.

Korhonen, H., Syvaoja, E.L. and Ahola-Luttila, H. (1995). Bactericidal effect of bovine normal and immune serum colostrum and milk against Helicobacter pylori. $J$. Appl.Bacter. 78:655- 662.

Korycka-dahl, M., Richardson, T. and Hicks, C.L. (1979): Superoxide of dismutase activity in bovine milk serum. J. Food Prot. 42: 867-871.

Kume, S. and Toharmat, T. (2001). Effect of colostral carotene and vitamin A on vitamin and health status of newborn calves. Livest. Prod. Sci., 68: 61-65.

Levay, P.F. and Viljoen, M. (1995). Lactoferrin: 
a general review. Haematologic. 80: 252 267.

Lindmark-Mansson, H. and Akesson, B. (2000). Antioxidative factors in milk. $\mathrm{Br} . \mathrm{Jr}$. Nutr. 84: 103-110.

Lonnerdal, B. and Lyer, S. (1995). Lactoferrin: molecular structure and biological function. Annl. Rev. Nutr. 15: 93-110.

Mann, S., Shandilya, U. K., Sodhi, M., Kumar, P., Bharti, V. K., Verma, P., Sharma. A., Mohanty. A., and Mukesh, M. (2016). Determination of antioxidant capacity and free radical scavenging activity of milk from native cows (Bos indicus), exotic cows (Bos taurus), and riverine buffaloes (Bubalus bubalis) across different lactation stages. Int. J. Dairy Sci. 66-70.

McEwan, A. D., Fisher, E. W., Selman, I. E., andPenhale, W. J. (1970). A turbidity test for the estimation of immune globulin levels in neonatal calf serum. ClinicaChimicaActa. 27(1), 155163.

Moretti, D. B., Nordi, W. M., Lima, A. L., Pauletti, P., and Machado- Neto, R. (2014). Enteric, hepatic and muscle tissue development of goat kids fed with lyophilized bovine colostrum. J. Ani. Physiol. Anim. Nutr. 98(2): 201-208.

Nagaraja, L. (2010). Evaluation of immunomodulatory potential of bovine colostrum for prevention of $E$. coli diarrhea in rabbits. M.V.Sc. Thesis submitted to Deemed University, IVRI, Izatnagar.
Nikolic, I., Stojanovic, I., Vujicic, M., Fagone, P., Mangano, K., Stosic-Grujicic, S. Nicoletti, F. and Saksida, T. (2017). Standardized bovine colostrum derivative impedes development of type 1 diabetes in rodents. Immunobiol. 222(2): 272-279.

Nireesha, G. R., Divya, L., Sowmya, C., Venkateshan, N. N. B. M., \&Lavakumar, V. (2013). Lyophilization/freeze dryingan review. International journal of novel trends in pharmaceutical sciences, 3(4), 87-98.

Pandey, N. N., Dar, A. A., Mondal, D. B., \&Nagaraja, L. (2011). Bovine colostrum: a veterinary nutraceutical. J. Vet. Med. Anim. Health. 3(3), 31-35.

Sanchez, L., Clavo, M. and Brock, J.H. (1992). Biological role of lactoferrin. Arch. Dis. Child. 67: 657-661.

Schweigert, F.J. and Eisek,W. (1990). Parenteral beta-carotene administration to cows: effect on plasma levels, lipoprotein distribution and secretion in the milk. Zeitschriftfuer Ernaehrungswissenschaft, 29: 184-191.

Shin, K., Tomita, M. and Lonnerdal, B. (2000). Identification of lactoperoxidase in mature human milk. J. Nutr. Biochem.11: 94-102.

Stelwagen, K., Carpenter, E., Haigh, B., Hodgkinson, A., Wheeler, T.T., 2009. Immune components of bovine colostrum and milk. J. Anim. Sci. 87, 3-9.

\section{How to cite this article:}

Dushyant Kumar Sharma, Debabrata Mondal, R. Raguvaran, Arvind Kumar Das and Narayani Yadav. 2020. Effects of Freeze Drying on Antioxidants and Immunoglobulins Level of Zebu Bovine Colostrum. Int.J.Curr.Microbiol.App.Sci. 9(08): 3404-3414. doi: https://doi.org/10.20546/ijcmas.2020.908.393 